\title{
MR. JUSTICE BRANDEIS: THE QUEST FOR REASON *
}

\author{
HENRY J. FRIENDLY $\dagger$
}

\begin{abstract}
Speaking in Lonisville, Kentucky, before the Mississippi Valley Historical Association, Judge Friendly noted in preface that Mr. Justice Brandeis had, throughout his life, kept Louisville "deep in his heart", never forgetting the place of his birth and early childhood. His keen concern in the development of the University of Louisville, for example, provided a lasting source of satisfaction. Yet, despite the temptation to essay an interpretation of the Justice in terms of the influence of the frontier, such a thesis must be discarded because "there is no evidence to support it." The major infuences on Brandeis' early development came not from the life of Louisville, but from his parents, who "drew their intellectual stimulus from the remarkable group of inmigrants, mainly from Bohemia, that inchuded the names of Brandeis, Dembitz, Wehle, Flexner and Taussig"; from "the formative year and a half that Brandeis spent at the Annen-Realschule in Dresden"; from the "great teachers of the Harvard Law School, which Brandeis entered only four years after the Langdellian revolution"; and from the infuence of Emerson wohich he encountered in Cambridge.
\end{abstract}

From an historian's standpoint, to choose this as the moment for discussing Mr. Justice Brandeis' work on the Supreme Court is like writing about medieval England on the verge of the publication of the Rolls Series, or on the Mittelalter on the eve of the appearance of the Monumenta. The complete files covering Brandeis' service on the Court from 1919 until his retirement in 1939 are in the hands of Professors Freund and Howe of the Harvard Law School and Professor Bickel of Yale, whose brilliant book, The Unpublished Opinions of Mr. Justice Brandeis, the first fruit of these papers, shows how great a feast is in store. Yet a former law clerk of the Justice may feel warranted in rushing in where a trained historian would fear to tread. For while the papers will sharpen the ridges and ravines, they will hardly alter the general topography of Brandeis' five hundred and twenty-eight published opinions, four hundred and fifty-four of these delivered for the Court.

Let me begin with a few general observations. Everyone who knew Brandeis was struck by his intensity. President Roosevelt recognized this when he took to addressing Brandeis as "Isaiah." This quality was manifest in Brandeis' appearance, in his acts and in his writings. His eyes, set deep in his sensitive and expressive face, would

* An address delivered in Louisville, Kentucky, at the annual meeting of the Mississippi Valley Historical Association on April 29, 1960.

$\dagger$ Judge of the United States Court of Appeals for the Second Circuit. Judge Friendly served as law clerk to Mr. Justice Brandeis during the October Term 1927 of the Supreme Court. 
flash the signal, whether of indignation, enthusiasm or a gentle irony. Despite his serenity, he was pre-eminently a fighter. He fought for the many causes that interested him while in private life; on more than one occasion, he had to fight for himself; and he did not stop fighting when he became a judge. This he conceived to be his duty. The intellectual satisfaction of having arrived at the correct decision meant little to him; the true satisfaction came only from the translation of that decision into reality. He knew nothing of what Judge Hand, in his moving tribute to Justice Cardozo, has called "the anguish which had preceded decision." 1 But once decision was made-and on many of the great issues it had been made long before the case was arguedthere was the engrossing task of endeavoring to persuade his colleagues, or at least four of them. To that task Brandeis summoned all his talents: his profound knowledge of men, his immense tact and personal charm, and the eloquence of his tongue and pen. Many of his opinions, both for the majority and in dissent, were first circulated as memoranda to his colleagues; and the extremely short interval between the argument of a case and the arrival of a Brandeis memorandum, perhaps of a dozen printed pages, must have suggested that even so rapid a worker had indulged in some advance activity. ${ }^{2}$

A consequence of this side of Brandeis' nature is that his opinions have a relentless quality. As Justice Frankfurter has said, they "march step by step towards demonstration, with all the auxiliary reinforcement of detailed proof." 3 No quarter is asked and none is given. Fact is piled on fact, proposition on proposition, until the right doctrine emerges in heavenly glory and the wrong view is consigned to the lowest circle of hell. It has been said, no doubt correctly, that Brandeis' style lacks the magic of those supreme composers of judicial literature, Holmes and Learned Hand. But the judicial Parnassus has room for more than two, and I find deep eloquence in the march of Brandeis' opinions. In some of the great ones, such as the dissents in the wiretapping case ${ }^{4}$ and the Oklahoma ice case ${ }^{5}$ and the concurring opinion

1 HaNd, The Spirit of Liberty 131 (2d ed. 1953).

2 Professor Hart's recent comment, Foreword: The Time Chart of the Justices, 73 HARV. L. REv. 84, 124 (1959), remarks on "the shortness of the time available and used for collective deliberation and for private study of argued cases prior to such deliberation" as a result of "the known practice of the Court of voting on an argued case at the conference which comes at the end of the week in which the case was argued." Brandeis sought to meet this problem in part by starting work on some of the great cases weeks or even months before the argument.

3 Frankfurter, Mr. Justice Brandeis and the Constitution, 45 HARv. L. Rev. 33, 104 (1931).

4 Olmstead v. United States, 277 U.S. 438 (1928).

5 New State Ice Co. v. Liebmann, 285 U.S. 262 (1932). 
in Whitney v. California, ${ }^{6}$ this relentless eloquence is screwed to such a pitch as to become almost agonizing. One hopes, as in listening to some passages of Wagner or Strauss, there is not much more to bear. In these opinions, one hears commingled the voice of the Hebrew prophet and the prayer of the Puritan poet:

\section{"What in me is dark}

Illumine, what is low raise and support;

That to the height of this great argument

I may assert eternal Providence,

And justify the ways of God to men."

It is time to leave style and to deal with substance. What was Brandeis' general legal philosophy? What were the particular lessons preached by this twentieth century prophet? The two questions are opposite sides of the same coin. Brandeis left no single testament where we can find his legal credo neatly packaged and ribboned. Unlike Holmes he had little use for universals. Indeed, Holmes mildly complained of this. In a well-known letter to Sir Frederick Pollock, he wrote that Brandeis

"the other day drove a harpoon into my midriff with reference to my summer occupations. He said you talk about improving your mind, you only exercise it on the subjects with which you are familiar. Why don't you try something new, study some domain of fact. Take up the textile industries in Massachusetts and after reading the reports sufficiently you can go to Lawrence and get a human notion of how it really is. I hate facts. I always say the chief end of man is to form general propositions-adding that no general proposition is worth a damn." ?

Brandeis would have agreed with the last remark and with that alone. Though it was Holmes who said, "general propositions do not decide concrete cases," 8 it was Brandeis who believed in this and acted upon it.

Professor Mason traces Brandeis' "natural bent toward inductive processes" as far back as the future Justice's youthful experience at the Annen-Realschule in Dresden. ${ }^{9}$ That bent was powerfully reinforced

6274 U.S. 357 (1927).

72 Holmes-Pollock Letrers 13 (Howe ed. 1941). Holmes recounts the same conversation in a letter of May 18, 1919, to Laski. 1 HolMrEs-LASKI LETTERs 20405 (Howe ed. 1953). Laski thought Brandeis' remark "very interesting." He adds, for Holmes' edification, "somewhere in Harnack there is a sentence on the early nominalists to the effect that they were tired of abstractions and demanded contact with the hard and concrete facts." Id. at 205.

8 Lochner v. New York, 198 U.S. 45, 76 (1905).

- Mason, Brandeis: A Free Man's Life 35 (1946). 
by his exposure to the early days of the case method at the Harvard Law School. ${ }^{10}$ It never left him. In 1922 he said of a corporate director, "facts, facts, facts are the only basis on which he can properly exercise his judgment," 11 and he thought the same rule applied to a lawyer or judge. Holmes mentions in a letter to Laski that "someone said of Brandeis, $\mathrm{He}$ is not afraid of a Balance Sheet"-a quality which Holmes characterized as "a great (secondary) advantage." 12 To have said that Brandeis was not afraid of balance sheets was one of the great understatements of all time: he positively revelled in them, and in statistics of all sorts. In part, this was the usual happiness of the craftsman in a field where he moves with facility and skill. More important, however, statistics furnished the data essential for decision; balance sheets and reports were the very stuff of Brandeis' dreams and insights. ${ }^{13}$ You will recall his advice that only after reading the reports on the textile industry could Holmes "go to Lawrence and get a human notion of how it really is."

Let me hasten to sound a warning lest you conclude that Brandeis became bogged down in details. True it is that he consumed facts in quantity and with relish, but these were simply the raw materials for his alchemy. As Professor Freund has said, "he was able to transform the little case before him into an instance of a larger truth; he had the art of seeing, as Holmes would say, the general in the particular." 14 Or, in Justice Frankfurter's words, "to no one less than to him was a case a discrete phenomenon. It was an organism." ${ }^{15}$

Using Brandeis' own method of induction, then, let us go to the reports and see how near we can arrive to some general notion of the man and of his contribution to our law.

I shall begin with decisions under the due process and equal protection clauses relating to the regulation of business and to taxation. I do this for two reasons. This field of law is not technical; indeed,

$10 I d$. at $34-38$.

$11 \mathrm{Id}$. at 418 .

122 Holmes-Laski LetTers 1135 (Howe ed. 1953). Holmes had given the quality a higher rating when he had said, in 1897, that "the man of the future is the man of statistics and the master of economics." HoLnes, The Path of the Law, in The Mind and Faith of Justice Holmes 71, 83 (Lerner ed. 1943).

13 The dissents in United Rys. \& Elec. Co. v. West, 280 U.S. 234, 255 (1930), St. Louis \& O'Fallon Ry. v. United States, 279 U.S. 461, 488 (1929), National Life Ins. Co. v. United States, 277 U.S. 508, 522 (1928), and Missouri ex rel. Southwestern Bell Tel. Co. v. Public Serv. Comm'n, 262 U.S. 276, 289 (1923), are enough to prove the point.

14 Freund, Mr. Justice Brandeis: A Centemial Memoir, 70 HaRv. L. Rev. 769, 783 (1957).

15 Frankfurter, Of Law and Men 186 (1956). 
that is one of the reasons why it has been said that judges should keep out of it altogether. And the subject is much in the public eye today, particularly because of Judge Hand's Holmes Lectures at Harvard in $1958^{16}$ and Professor Wechsler's response in 1959.17

I know of no evidence that Brandeis was afflicted by any such intellectual doubts as to judicial review in this area as led Judge Hand to state that the power of courts to declare legislation unconstitutional "should be confined to occasions when the statute or order was outside the grant of power to the grantee, and should not include a review of how the power has been exercised," 18 a proposition perhaps easier to state than to apply. To be sure, there are remarks, notably in Whitney v. California ${ }^{19}$ and in New State Ice Co. v. Liebmann, ${ }^{20}$ which indicate that, had Brandeis deemed the question open, he would have been receptive to the view that the due process clause was limited to questions of procedural fairness. But he regarded that issue as foreclosed and, I believe, without any real regret. What concerned him was not the existence of the power but the manner of its exercise.

What Brandeis deemed the proper approach to the challenge of a regulatory statute on due process grounds is exemplified by his dissent in Jay Burns Baking Co. v. Bryan. ${ }^{21}$ There, a Nebraska statute fixing maximum weights for bread was attacked as a denial of due process; the Court had previously upheld a statute fixing minimum weights. ${ }^{22}$ As Brandeis saw the issue, it was:

". . . whether the prohibition of excess weights can reasonably be deemed necessary; whether the prohibition can reasonably be deemed an appropriate means of preventing short weights and incidental unfair practices; and whether compliance with the limitation prescribed can reasonably be deemed practicable. The determination of these questions involves an enquiry into facts. Unless we know the facts on which the legislators may have acted, we cannot properly decide whether they were (or whether their measures are) unreasonable, arbitrary or capricious. Knowledge

16 HaNd, The Bill of Rights (1958).

17 Wechsler, Tozeard Neutral Principles of Constitutional Law, 73 Harv. L. Rev. 1 (1959). See also Black, The People and the Court: Judicial Review IN A DEMOCRACY (1960).

18 HAND, op. cit. supra note 16, at 66.

19274 U.S. 357, 373 (1927). "Despite arguments to the contrary which had seemed to me persuasive, it is settled that the due process clause of the Fourteenth Amendment applies to matters of substantive law as well as to matters of procedure." See also Jay Burns Baking Co. v. Bryan, 264 U.S. 504, 519 (1924): "but, under the due process clause as construed, we must determine . . ." (Emphasis added.)

20285 U.S. 262, 311 (1932).

21264 U.S. 504, 519 (1924).

22 Schmidinger v. City of Chicago, 226 U.S. 578 (1913). 
is essential to understanding; and understanding should precede judging. Sometimes, if we would guide by the light of reason, we must let our minds be bold. But, in this case, we have merely to acquaint ourselves with the art of breadmaking and the usages of the trade; with the devices by which buyers of bread are imposed upon and honest bakers or dealers are subjected by their dishonest fellows to unfair competition; with the problems which have confronted public officials charged with the enforcement of the laws prohibiting short weights, and with their experience in administering those laws." ${ }^{23}$

There follow fourteen pages devoted to painstaking exposition of these matters, pages representing many hours of work by the Justice and, I suppose, his law clerk without, as examination of the briefs shows, any substantial assistance from counsel. The experience not only in Nebraska but in many other states is reviewed in depth. We learn what problems had been found when minimum weights only were fixed, what public officials recommended, what legislatures did, what the results were. And "in the light of all facts which may enrich our knowledge and enlarge our understanding," ${ }^{24}$ the Justice is convinced that the Nebraska legislature had much reason for doing what it did: ergo, the statute passed the constitutional test.

The approach thus taken by Brandeis to questions of due process on the bench had, of course, been prefigured by the technique he had developed for arguing such cases at the bar. His methodology consisted of marshaling for the Court materials from economic and scientific journals, legislative hearings and reports, and regulations adopted by other states relating to the problem to which the statute under attack had been addressed. Today we may think no procedure could be more obvious, but that is Columbus and the egg. In 1908 the technique was deemed such an innovation as to elicit specific comment from the Supreme Court, ${ }^{25}$ and after half a century it is still known as the "Brandeis brief."

We may obtain further light on Brandeis' approach by traveling eastward from the bakeries of Nebraska to those of Utica, New York, and backward from Mr. Justice Brandeis in 1924 to Lochner v. New York $^{26}$ in 1905. New York had regulated not the weight of bread but the hours of breadmakers. Five justices, speaking through a

23264 U.S. at 519-20. Note that the sentence beginning "if we would guide by the light of reason" was repeated eight years later in the more famous dissent in New State Ice Co. v. Liebmann, 285 U.S. 262, 311 (1932). Brandeis, like Bach and Handel, saw nothing wrong in plagarizing from himself.

24264 U.S. at 534.

25 See Muller v. Oregon, 208 U.S. 412, 419 (1908).

26198 U.S. 45, 74 (1905). 
New Yorker, Mr. Justice Peckham, thought such an act was beyond the bounds: "clean and wholesome bread does not depend upon whether the baker works but ten hours per day or only sixty hours a week." ${ }^{27}$ The first Mr. Justice Harlan challenged this; in an opinion that was a predecessor of the typical Brandeis dissent, he undertook to show that bad hours for bakers did or at least might mean bad bread. Holmes was impatient with all this detail. To him the test was whether "a rational and fair man necessarily would admit that the statute proposed would infringe fundamental principles as they have been understood by the traditions of our people and our law." ${ }^{28}$ Unlike the Brandeis formulation, Holmes' test has little concern with the reasons behind the particular legislation; whether the challenged statute conforms to the fundamental principles required to make it due process "will depend on a judgment or intuition more subtle than any articulate major premise." Therefore, according to Holmes, "it does not need research to show that no . . . sweeping condemnation can be passed upon the statute before us." Brandeis, like Harlan, would have thought it did.

A particularly neat illustration of this difference in approach is furnished by the dissents of the two Justices in Untermyer v. Anderson, ${ }^{29}$ which held that the due process clause of the fifth amendment forbade Congress from making the gift tax retroactive even for ten days. Holmes was satisfied with an opinion of nineteen lines. $\mathrm{He}$ would not "go into the question of constitutionality beyond saying that I find it hard to state to myself articulately the ground for denying the power of Congress to lay the tax." Beyond that he added, somewhat wistfully and, as we now know, all too truly: "we all know that we shall get a tax bill every year. I suppose that the taxing act may be passed in the middle as lawfully as at the beginning of the year." Brandeis begins simply enough: "to what Mr. Justice Holmes has said, I add this." He adds eight pages with as many footnotes. $\mathrm{He}$ is not content with saying that "tested by the standard of reasonableness commonly adopted by man-use and wont-that action appears to be reasonable." Nor does he rest after pointing out that the Court had sustained retroactive federal tax laws before. The Brandeis explanation is in specifics. "Each of the fifteen income tax acts adopted from time to time during the last sixty-seven years has been retroactive, in that it applied to income earned, prior to the passage of the act, during the calendar year." He cites each of the fifteen to prove the accuracy of 
his statement and to afford the means for verification. This compilation is followed by a survey of other tax statutes which Congress had made retroactive to the beginning of the year and of decisions applying them. Nor is this all. The reader is next taken on a journey which tarries a good while in England, with extensive citation of British statutes, treatises and decisions, and then pauses in Ireland, Canada, Newfoundland, Australia, New Zealand, South Africa, France and Italy. Only after this historical and geographical tour has been completed is Brandeis willing to rest with a reference to the presumption of legislative validity.

I would not multiply examples, but I cannot refrain here from citing an equal protection clause case of the year during which I served as Brandeis' law clerk, Louisville Gas \& Elec. Co. v. Coleman.30 Kentucky sought to impose its recording tax of twenty cents per hundred dollars on the utility's nineteen million dollar issue of thirty-year mortgage bonds. The company claimed that the levy amounted to a denial of equal protection of the laws inasmuch as no such tax was imposed on loans maturing within five years. At first sight the claim was by no means frivolous. How justify a thirtyeight thousand dollar tax on a nineteen million dollar loan maturing in sixty months when there would be none on a loan of the same amount becoming due in fifty-nine? Brandeis set out to answer this. As usual, the record and briefs gave little help. But Brandeis' labors -here I am on firm ground even among historians when I add those of his law clerk-yielded an answer. Nine states included a mortgage recording tax as a part of their revenue systems. While such a tax had several advantages-ease and certainty of collection being the most obvious one-it also had a glaring weakness. Being imposed only once, at the time of recording, it bore more heavily on short-term than on long-term transactions. Louisville Gas \& Electric would pay only one-sixth as much per dollar per annum for recording the thirty-year mortgage on its utility properties as would an individual mortgagor for recording a five-year mortgage on his house. The seeming equality of imposing the same tax on all mortgages regardless of term thus turned out to be the greatest inequality. Different states had sought to mitigate this inequity in various ways; some, for instance, imposed lower rates on mortgages of short terms. Kentucky, not without reason, had decided to exempt the short-term mortgages altogether. It found that the short-term loans were usually made by local lenders who were subject to property taxation on the debt, whereas the 
long-term loans were made by out-of-state lenders who escaped such taxation. To be sure, there were some loans made by outlanders for terms less than five years and others by inlanders for more than five years, but the legislative line had to be drawn somewhere; and after an amount of backing and filling which showed thorough consideration, the Kentucky legislature had opted for five years.

The results of this exploration were embodied in one of those typical Brandeis memoranda which were circulated to the brethren so shortly after argument as to have betrayed advance study. For, in addition to the material that I have summarized, the memorandum included a rather complete survey of the various exemptions and graduations which the Court had sustained against equal protection attack and a more detailed analysis of the decisions sustaining provisions for no taxes or lower taxes on small transactions without, as in the case of the usual progressive income tax, applying the same exemption ${ }^{31}$ or lower rate ${ }^{32}$ to the initial brackets of the large. Persuasive as the result seemed to the Justice and his law clerk, it won no votes save the usual ones of Holmes and Stone. ${ }^{33}$ I remember that when the Justice returned from conference late Saturday afternoon, I expressed dismay, not so much over the downfall of the particular statute (which I supposed the Commonwealth would survive) as over the precedent that the Court was creating. I recall the Justice's Olympian calm. "Don't be concerned," he said. "A future Court will pay no more heed to this decision than today's Court is paying to the cases we cited to them." History has proved how right he was.

Although Brandeis applied his due process and equal protection test with an even hand, he applied it con amore in those cases where the statute under attack tracked his own social philosophy, as in the case of legislation favoring the individual against the corporation or the small business against the large. Here the opinions, such as the dissent in Quaker City Cab Co. v. Pennsylvania, ${ }^{34}$ truly sing:

"the present heavier imposition [against corporations] may be a survival of an early effort to discourage the resort to that form of organization. The apprehension is now less common. But there

31 See Citizens' Tel. Co. v. Fuller, 229 U.S. 322 (1913) ; Quong Wing v. Kirkendall, 223 U.S. 59 (1912) ; Magoun v. Illinois Trust \& Sav. Bank, 170 U.S. 283 (1898).

32 See Metropolis Theatre Co. v. City of Chicago, 228 U.S. 61 (1913); Clark v. Titusville, 184 U.S. 329 (1902).

33 At some point Holmes determined to write a characteristically short dissent of his own, to the effect that the Kentucky legislature had found a clear distinction between large transactions of the money market and small ones for private need, that five years was the line marking the distinction, and that Holmes could not say the legislature was wrong. This picked up the additional vote of Justice Sanford, who did not join Holmes and Stone in concurring in the Brandeis dissent.

34277 U.S. 389, 410-11 (1928). 
are still intelligent, informed, just-minded and civilized persons who believe that the rapidly growing aggregation of capital through corporations constitutes an insidious menace to the liberty of the citizen; that it tends to increase the subjection of labor to capital; that, because of the guidance and control necessarily exercised by great corporations upon those engaged in business, individual initiative is being impaired and creative power will be lessened; that the absorption of capital by corporations, and their perpetual life, may bring evils similar to those which attended mortmain; that the evils incident to the accelerating absorption of business by corporations outweigh the benefits thereby secured; and that the process of absorption should be retarded."

Brandeis knew extremely well at least one "intelligent, informed, justminded and civilized person" holding such views! ${ }^{\mathbf{3 5}}$

One who wonders whether Brandeis ever failed to find reason to support legislative regulation of business would be in good company. When Holmes wrote Sir Frederick Pollock of Brandeis' dissent to Holmes' opinion in Pennsylvania Coal Co. v. Mahon, ${ }^{36}$ Pollock responded "that if Brandeis' dissent were right the Fourteenth Amendment would be 'eviscerated." ${ }^{37}$ Yet there were limits beyond which Brandeis would not go even in this area. In Louisville Joint Stock Land Bank v. Radford, ${ }^{38}$ Brandeis wrote the opinion invalidating the Frazier-Lemke amendment to the Bankruptcy Act which drastically attenuated the rights of a mortgagee by permitting the farmer to retain possession for five years upon the payment of a reasonable rental and then to acquire the property for its appraised value. Here the same techniques usually devoted by Brandeis to sustaining a legislative act

35 The theme announced in the Quaker City case was elaborately worked out two years later in the unpublished dissent in Stratton v. St. Louis S.W. Ry., ultimately dismissed for want of jurisdiction, 282 U.S. 10 (1930). BICKEI, THE UNPUBLISEED OPINIONS of MR. JUSTTCE BRANDEIS 140 (1957). It resounded again in Brandeis' dissent in the Florida chain-store tax case, Louis K. Liggett Co. v. Lee, 288 U.S. 517, 541,580 (1933). I recall that, having had some business in Tallahassee, I told the Justice that I feared many of the Florida legislators had been more influenced by the independent drug store lobby than by the philosophical and sociological ideas with which he credited them; he did not seem amused. Professor Freund, the law clerk of that term, has also noted that "the people of Florida might be astonished to learn how profoundly wise they were. . . "Freund, supra note 14, at 784 . It is interesting that Mr. Justice Stone declined to join in this dissent, thinking that Brandeis was "too much an advocate of this particular legislation"; Stone concurred in Mr. Justice Cardozo's dissent. See Mason, Harlan Fiske Stone: PIllar of the Law 315 (1956).

36260 U.S. 393 (1922), holding invalid a Pennsylvania statute which forbade the use of anthracite mining rights in such a way as to cause the subsidence of a dwelling.

372 Holmes-Pollock Letrers 111 (Howe ed. 1941). Pollock's ideas of Pennsylvania geography were not very accurate. He wrote: "there was no such case on the facts, I suppose, as that the Coal Co. threatened and intended to let down the whole city of Philadelphia and had refused all offers of reasonable compensation."

38295 U.S. 555, 601 (1935). 
were employed for its destruction. Despite the hardships of previous depressions and the greater hardships of the Great Depression, no other statute had attempted such drastic relief; the act under attack not merely postponed the mortgagee's remedy or prevented his driving an unconscionable bargain, but deprived him forever of his basic right to have the property sold to satisfy his lien, and before sale to control the property and have the rents and profits applied to satisfy the debt. In language reminiscent of Holmes' Pennsylvania Coal opinion from which Brandeis had dissented, the Justice condemned the act as taking from the mortgagee without compensation and giving to the mortgagor "rights in specific property which are of substantial value," despite the command of the fifth amendment "that, however great the Nation's need, private property shall not be thus taken even for a wholly public use without just compensation."

Another of today's great constitutional debates is whether a different and more stringent test is to be applied to legislation claimed to impinge on the individual liberties guaranteed by the Bill of Rights than is applied to statutes of a different sort-whether, as is sometimes said, these guarantees occupy a "preferred position."

Brandeis was still on the Court at the time of the famous "footnote four" to Mr. Justice Stone's opinion in United States v. Carolene Prods. $\mathrm{Co}^{39}$ That footnote made what has now become the highly controversial suggestion that "there may be a narrower scope for operation of the presumption of constitutionality when legislation appears on its face to be within a specific prohibition of the Constitution, such as those of the first ten amendments, which are deemed equally specific when held to be embraced within the Fourteenth." While Brandeis concurred in the opinion, nothing in published sources shows that he focused on the footnote. There was no reason for him to do so. The Carolene case concerned the constitutionality of the Federal Filled Milk Act of $1923,{ }^{40}$ a topic far removed from the personal liberties guaranteed by the Bill of Rights. There was neither need nor, on Brandeis' usual view, justification for discussing individual liberties. Moreover, the first paragraph of the footnote as published, as distinguished from the original draft by Stone's law clerk and Stone's minor revision of it, was rather meaningless inasmuch as legislation which "appears on its face to be within a specific prohibition of the Constitution" would be invalid on any view. ${ }^{41}$ And the second and third paragraphs which supply the

39304 U.S. 144, 152 n.4 (1938).

4042 Stat. 1486 (1923), 21 U.S.C. $\$ \S 61-64$ (1958).

41 The draft of the first paragraph as circulated stated: "different considerations may apply and one attacking the constitutionality of a statute may be thought to bear 
rationale-that in this area we are dealing with obstructions to the democratic process itself-sounded in terms of "it is unnecessary to consider" and "nor need we enquire" whether the germinating doctrine was sound or not.

It would seem that Brandeis' repeated insistence on avoiding constitutional issues not squarely presented would have led him to agree with the position, later taken by Mr. Justice Frankfurter, disapproving such a "way of announcing a new constitutional doctrine." 42 As to what his views would have been on the merits, the published materials afford no basis for reliable inference. The advocates of the "preferred position" doctrine can point to the fact that the relatively few instances in which Brandeis struck down state legislation under the due process clause included a Nebraska statute forbidding the teaching of any modern foreign language in the primary grades, ${ }^{43}$ and an Oregon act outlawing parochial schools. ${ }^{44}$ The profundity of Brandeis' belief in freedom of speech is beyond all doubt. He followed Holmes in applying the "clear and present danger" test to the Espionage Act of $1917^{45}$ and delivered powerful dissents on the same theme. ${ }^{46}$ The world's literature knows no declaration of independence more resounding than his concurring opinion in Whitney $v$. California $;{ }^{47}$ there Brandeis goes back to Thucydides for the great phrase from Pericles' oration: "they believed liberty to be the secret of happiness and courage to be the secret of liberty." He deeply believed also in maintaining, for those accused of crime, the protections against overzealous agents of government afforded by the Bill of Rights, the common law, and fundamental notions of decency. ${ }^{48}$ However, Whitney excepted, the cases required

a lighter burden, when the legislation aims at restricting the corrective political processes, which can ordinarily be expected to bring about repeal of undesirable legislation." Apparently the watering down of the paragraph, on the one hand, and, on the other, a broadening of it to include all provisions of the Bill of Rights, rather than those protecting "the corrective political processes" to which alone the reason of the doctrine would apply, stemmed from Chief Justice Hughes. See MAson, $o p$. cit. supra note 35 , at $512-15$.

42 Kovacs v. Cooper, 336 U.S. 77, 91 (1949).

43 Meyer v. Nebraska, 262 U.S. 390 (1923). This case produced the unusual lineup of Brandeis concurring in an opinion of McReynolds over a dissent by Holmes.

44 Pierce v. Society of Sisters, 268 U.S. 510 (1925).

4540 Stat. 217 (1917) (codified in scattered sections of 18, 22, 50 U.S.C.), Schenck v. United States, 249 U.S. 47 (1919).

46 Pierce v. United States, 252 U.S. 239, 253 (1920); Schaefer v. United States, 251 U.S. 466, 482 (1920).

47274 U.S. 357,372 (1927).

48 Olmstead v. United States, 277 U.S. 438, 483 (1928); Ziang Sung Wan v. United States, 266 U.S. 1, 14-17 (1924) ; Burdeau v. McDowell, 256 U.S. 465, 476-77 (1921). 
no pronouncement on the validity of statutes, and there was thus no occasion for determining the test to be applied. ${ }^{49}$

My guess is that Brandeis would not have formulated the test of constitutionality differently when a statute was alleged to infringe personal liberties than when it was claimed to violate rights of property; he would have subjected such laws to the same test of reason in the light of facts that he applied to the Nebraska bread statute. But while the statement of the test would have been the same, the result would not necessarily have been so. A test of rationality is inevitably applied against a judge's own background of basic belief; in this field despite every effort at neutrality a judge's mind cannot be tabula rasa. Believing that "the economic and social sciences are largely uncharted seas," Brandeis approached laws affecting business hospitably even when the law was antipathetic to him. ${ }^{50}$ In that area, therefore, a relatively small amount of evidence would bring the legislation within the domain of rationality. The basic freedoms were quite another matter. Here we are in no "uncharted seas"; we are dealing with values which, in Brandeis' view, had stood the test of time and were rooted in the lessons of history and his reading of human nature. Here we lean not on fragile notions of economics, believed today and discarded tomorrow, but on the permanent and enduring teachings of the Hebrew prophets, of fifth century Athens, of seventeenth century England and of eighteenth century America. For legislation to overcome the validity of these lessons, as embodied in the Bill of Rights, strong proof would be required. The threshhold of judicial conviction would thus have been higher; more reasons would have had to be adduced to show the accused legislation was reasonable. Brandeis' result, therefore, would not, I believe, have been very different from the conclusion that would flow from the doctrine giving a preferred position to constitutional attack on legislation affecting the basic liberties, and the whole question may be largely a semantic one.

$49 \mathrm{~A}$ case that might have led to such a determination is Gilbert v. Minnesota, 254 U.S. 325 (1920). There the Court sustained a Minnesota statute prohibiting the teaching of pacifism. Brandeis dissented on the ground that the statute "interferes with federal functions and with the right of a citizen of the United States to discuss them." Hence he saw "no occasion to consider whether it violates also the Fourteenth Amendment." He adds that if the liberty guaranteed by the Constitution protected, as the Court had held, against various state regulatory laws, it was difficult to believe that it did "not include liberty to teach, either in the privacy of the home or publicly, the doctrine of pacifism; so long, at least, as Congress has not declared that the public safety demands its suppression." The last clause might be claimed to show that Brandeis would have sustained repressive legislation even in this area; but there is the protective "at least" and the evidence is too thin to warrant any conclusion.

50 "The objections to the proposal [requiring certificates of public convenience and necessity to enter the ice business] are obvious and grave. The remedy might bring evils worse than the present disease. The obstacles to success seem insuperable." New State Ice Co. v. Liebmann, 285 U.S. 262, 280, 309-10 (1932). 
No discussion of Brandeis' approach to constitutional issues would be complete without at least a word on his zeal to avoid them. The unpublished opinions show how, as early as 1920, less than four years after taking his seat on the Court, Brandeis was already protesting against the decision of constitutional issues in litigation which he thought collusive and therefore not a "case or controversy" within the federal judicial power. ${ }^{51}$ The theme of that early opinion recurs again and again, until its final and definitive enunciation in the case involving the constitutionality of the act constituting the Tennessee Valley Authority, ${ }^{52}$ where he majestically reviews the various ways in which the Court has declined to determine the constitutionality of legislation unless such a decision was required.

There were many reasons why Brandeis felt so keenly about this principle. He was sincere in thinking that judicial invalidation of legislation was an awful responsibility in the literal meaning of the adjective; as he states in the $T V A$ case: "the Court has frequently called attention to the 'great gravity and delicacy' of its function in passing upon the validity of an act of Congress." ${ }^{53}$ This attitude accorded also with his deep sense of the need for restraint, both individual and collegial. Professor Freund has told how fond the Justice was of quoting Goethe's aphorisms that "self-limitation is the first mark of the master," and "care is taken that the trees do not scrape the skies." 54 Behind it also, I suspect, was the quality of mind on which I remarked at the outset-Brandeis' profound belief in the need for facts. Often these were badly enough presented even when both sides knew the constitutional issue was unavoidable. But what confidence could the Court have that it was getting the facts, of learning wie es eigentlich gewesen war, when the validity of legislation was not necessarily raised in litigation between two parties, one of whom would genuinely suffer from the statute and the other would have an equal interest in its enforcement?

Judge Hand has spoken of the apocalyptic quality of Brandeis. So it is appropriate if, for my summation, I go to the great words in the Gospel according to John: "the truth shall make you free." Surely

51 See BICKEL, op. cit. supra note 35, at 1-20, dealing with Atherton Mills v. Johnston, ultimately dismissed as moot, 259 U.S. 13 (1922).

52 Ashwander v. TVA, 297 U.S. 288, 341 (1936). Attention has often been called to Brandeis' departure from his own precepts in Willing v. Chicago Auditorium Ass'n, 277 U.S. 274 (1928), overruled sub silentio in Aetna Life Ins. Co. v. Haworth, 300 U.S.S. 227 (1937) (Brandeis concurring), and in the constitutional ground asserted for Erie R.R v. Tompkins, 304 U.S. 64 (1938). As to Mr. Justice Stone's role in framing the opinion in the Erie case, see MASON, op. cit. supra note 35, at 476-81.

53297 U.S. at 345. (1958).

54 Freund, The Liberalism of Justice Brandeis, 10 AM. JEwISH ARchIves 37 
this was the essence of Brandeis' teaching. He was the authentic child of the Aufklärung; he had none of today's doubts as to whether the truth could be ascertained. He did not believe with the evangelist that this truth could be found by abiding in the Word or in becoming the disciple of any leader. Neither did he think it came from intuition or from speculation in metaphysics. He thought it could and would come only from the relentless, disinterested and critical study of facts. That is a lesson worth pondering today. 